\title{
PEMBUATAN SISTEM INFORMASI ADMINISTRASI KERJA PRAKTEK DAN PENGABDIAN MASYARAKAT BERBASIS WEBSITE
}

\section{Muhammad Fawaz Najib Risal, Nia Ambarsari, Edy sutoyo}

Program Studi Sistem Informasi, Universitas Telkom, Indonesia.

Email: fawaznajib@student.telkomuniversity.ac.id, niaambarsari@telkomuniversity.ac.id, edisutoyo@telkomuniversity.ac.id

\begin{abstract}
Abstrak
Tujuan dari penelitian ini adalah untuk mengetahui fitur atau layanan yang terdapat pada Website Kerja praktek dan pengabdian masyarakat pada modul Mahasiswa. Kerja Praktek dan Pengabdian kepada Masyarakat (KPPM) merupakan salah satu mata kuliah wajib di Fakultas Teknik Industri Universitas Telkom. Fakultas Teknik Industri merupakan salah satu Fakultas yang ada di Telkom University yang memiliki visi menjadi penelitian dan berjiwa wirausaha, berperan aktif dalam pengembangan ilmu pengetahuan di bidang sistem industri berbasis teknologi informasi yang berkontribusi terhadap perekonomian nasional. Namun Fakultas Teknik Industri memiliki kendala dalam mengelola manajemen kerja dan pengabdian masyarakat yang sebenarnya, namun penelitian ini hanya membahas modul mahasiswa. Sistem tersebut dinilai kurang efisien, dan belum ada sistem manajemen kerja dan pengabdian masyarakat yang sebenarnya, oleh karena itu diperlukan adanya sistem informasi kerja dan pengabdian masyarakat yang aktual berbasis website ini untuk membantu proses pengelolaan pekerjaan dan masyarakat yang sebenarnya. mahasiswa pengabdian dari Sekolah Tinggi Teknik Industri. Selain itu, sistem informasi berbasis website ini menggunakan metode black box testing dan usability testing. Hasil uji fungsi black box sistem dapat berjalan dengan normal, sedangkan dari hasil uji usability berdasarkan jawaban responden didapatkan nilai rata-rata 78 poin. Dapat dikatakan bahwa situs web manajemen kerja dan layanan masyarakat yang sebenarnya adalah kategori yang baik untuk digunakan oleh siswa.
\end{abstract}

Kata Kunci: Sistem Informasi; Telkom; Kerja Praktek Dan Pengabdian Masyarakat.

\begin{abstract}
The purpose of this study was to find out the features or services contained on the Practical Work Website and community service in the Studen module. Practical Work and Community Service (KPPM) is one of the compulsory subjects at the Faculty of Industrial Engineering, Telkom University. The Faculty of Industrial Engineering is one of the faculties at Telkom University which has a vision of being research and entrepreneurial, playing an active role in the development of knowledge in the field of information technology-based industrial systems that
\end{abstract}


contribute to the national economy. However, the Faculty of Industrial Engineering has obstacles in managing work management and actual community service, but this study only discusses the student module. The system is considered inefficient, and there is no actual work management and community service system, therefore it is necessary to have an actual work and community service information system based on this website to assist the actual work and community management process. service student from the College of Industrial Engineering. In addition, this website-based information system uses black box testing and usability testing methods. The results of the black box system function test can run normally, while the usability test results based on the respondents' answers get an average value of 78 points. It can be said that the real work management and community service website is a good category for students to use.

Keywords: Extreme Programming; Website; Blackbox testing; Usability testing.

Diterima: 20-12-2021Ｄirevisi: 12-01-2022Ｄiterbitkan: 20-01-2022

\section{Pendahuluan}

Kerja praktek dan pengabdian masyarakat merupakan salah satu mata kuliah wajib di Telkom University. Dalam prakteknya, kerja praktek dan pengabdian kepada masyarakat merupakan proses belajar bekerja di suatu perusahaan/lembaga. Tujuannya untuk mendapatkan pengalaman kerja, memahami lingkungan kerja dan mengamati setiap rencana studi sesuai dengan kemampuan masing-masing, kemudian bertanggung jawab kepada pembimbing akademik. Memberikan kerja praktek dan pengabdian kepada masyarakat bagi setiap mahasiswa. Telkom University mengimplementasikannya dengan menawarkan mata kuliah kerja praktek dan pengabdian masyarakat di setiap program studi seluruh perguruan tinggi yang ada termasuk Fakultas Teknik Industri (HS, 2020).

Dalam kegiatan manajemen kerja dan pengabdian masyarakat Institut Teknik Industri yang sebenarnya masih menggunakan prosedur lama, dan penelitian hanya menjelaskan permasalahan pada modul siswa, mulai dari siswa masih menerima informasi menggambar. Karya nyata tutor akademik dan file pengabdian masyarakat dan pembekalan memberikan siswa pekerjaan nyata dan pengabdian masyarakat melalui file sharing di media sosial. File-file ini akan didistribusikan ke setiap kelas sehingga informasi dapat dikomunikasikan secara menyeluruh kepada siswa (Saputra, 2021).

Siswa juga mengumpulkan laporan dan presentasi slide dokumen seperti kerja nyata dan pengabdian masyarakat harus dikirim melalui email, materi dan jadwal pembekalan masih diberitahukan melalui media sosial, log masih menggunakan formulir, dan mahasiswa yang menyerahkan laporan harus menghubungi setiap dosen untuk mengatur tanggal presentasi, yang kurang efisien bagi guru dan mahasiswa. Oleh karena itu, perlu dilakukan perubahan sistem manajemen kerja nyata dan pengabdian masyarakat di Perguruan Tinggi Teknik Industri (Ghufron, 2018).

Di era sekarang ini, kemajuan ilmu pengetahuan dan teknologi semakin luas. Teknologi Indonesia berkembang semakin pesat, mendorong manusia untuk berinovasi 
dan menciptakan hal-hal baru. Hal-hal baru ini akan digunakan untuk memajukan pekerjaan di masa depan. pemanfaatan teknologi informasi semakin menjanjikan.Meningkatkan efisiensi kerja karena dapat mempercepat penyampaian informasi. Dalam hal ini penerapan teknologi informasi melalui media jaringan adalah website telah diimplementasikan di beberapa perguruan tinggi di Indonesia, website memuat informasi yang banyak sehingga mudah digunakan, bentuk informasi berupa teks, grafik, gambar, suara dan video Website dapat diakses melalui browser dan terkoneksi dengan internet, sehingga pengguna hanya dapat dengan mudah mengaksesnya melalui browser laptop/PC atau smartphone (Harto, 2018).

Melihat permasalahan yang ada dalam manajemen kerja aktual mahasiswa dan pengabdian kepada masyarakat, maka perlu digunakan teknologi informasi aplikasi berbasis website untuk mempermudah manajemen kerja aktual mahasiswa dan pengabdian kepada masyarakat di Sekolah Tinggi Teknik Industri. Untuk membantu siswa melihat informasi pengawas menggambar, tugas akademik dan dokumen laporan kerja dan pengabdian masyarakat yang sebenarnya di situs web kerja dan pengabdian masyarakat yang sebenarnya, gunakan akun masing-masing siswa, disediakan oleh administrator FRI, dan melamar di situs web ini. Siswa juga dapat mengirim dokumen seperti sebagai laporan kerja nyata dan pengabdian masyarakat, slide presentasi, dan dokumen kerja nyata dan layanan masyarakat lainnya. Mahasiswa juga dapat mengecek jadwal perkuliahan yang diatur oleh dosen di website (Mandag et al., 2017).

Dengan adanya fungsi tersebut dapat membantu mahasiswa dalam pengelolaan kerja praktek dan pengabdian masyarakat di Perguruan Tinggi Teknik Industri. Adapun tujuan dari penelitian ini berdasarkan rumusan masalah di atas adalah untuk mengetahui fitur atau layanan yang terdapat pada Website Kerja praktek dan pengabdian masyarakat pada modul Mahasiswa, mengetahui rancangan aplikasi Website kerja praktek dan pengabdian masyarakat pada modul mahasiswa, dan mengetahui metode apa yang digunakan dalam pembuatan website administrasi kerja praktek dan pengabdian masyarakat

\section{Tinjauan Pustaka}

a. Sistem Informasi

Sistem merupakan suatu rangkaian dari dua atau lebih komponen-komponen yang saling berkaitan, yang berintreaksi untuk mencapai satu tujuan. Sistem terdiri dari tiga unsur yaitu input (masukan), proses, output (keluaran). Input yaitu komponen penggerak dimana sistem dioperasikan, proses yaitu aktivitas yang dapat mentransformasikan input menjadi output, sedangkat output adalah hasil operasi yang dioperasikan atau tujuan dari pengoprasian suatu sistem. Informasi merupakan data yang sudah dioleh menjadi sebuah bentuk yang bermafaat bagi pengguna (Sudjiman \& Sudjiman, 2018).

Sistem informasi merupakan komponen-komponen yang saling terhubung dan bekerja sama untuk mengumpulkan, memproses, menyimpan, dan menyebarkan informasi dengan memanfaatkan sumber daya manusia, dokumen, teknologi, dan prosedur oleh manajemen untuk mendukung pengambilan keputusan, koordinasi, 
pengendalian dan memberikan gambaran aktivitas di perusahaan yang lebih lanjut diproses untuk menjadi informasi dan didistribusikan ke para pengguna (Sidh, 2013).

b. Extreme Programming

Extreme programming adalah salah satu metode pengembagan yang turunan dari metode agile development. Agile development merupakan metode pengembangan yang dapat dilakukan dengan cepat atau dalam artian pemenuhan kebutuhan perangkat lunak atau sistem informasi yang melibatkan pengguna yang tujuannya meminimalisir kesalahan pengembangan (Fathoni et al., 2020).

c. Black-box Testing

Black box atau pengujian fungsional, pengujian fungsional dikembangkan berdasarkan fungsi sistem, yaitu penguji membutuhkan informasi tentang data input dan output yang diamati dalam perangkat lunak, tetapi tidak tahu bagaimana program atau sistem bekerja. Penguji lulus uji kotak hitam dan fokus pada fungsi program uji standar ini. Penguji menganggap program sebagai kotak hitam dan tidak peduli dengan struktur internal program atau sistem (Lewis, 2004).

d. Usability Testing

Salah satu cara untuk mengevaluasi produk adalah dengan menggunakan teknik Usability Testing yaitu cara mengukur kelayakan suatu aplikasi. Proses evaluasi produk melibatkan pengujian sampel pengguna secara langsung (Patzer \& Moodie, 2004).

\section{Metodologi Penelitian}

a. Model Konseptual

Model konseptual adalah alat untuk memahami, melaksanakan dan mengevaluasi penelitian sistem informasi, yang menggabungkan paradigma design science dan behavior science sistem informasi (Simarmata et al., 2021). Berikut adalah ilustrasi Model Konseptual pada gambar di bawah ini.

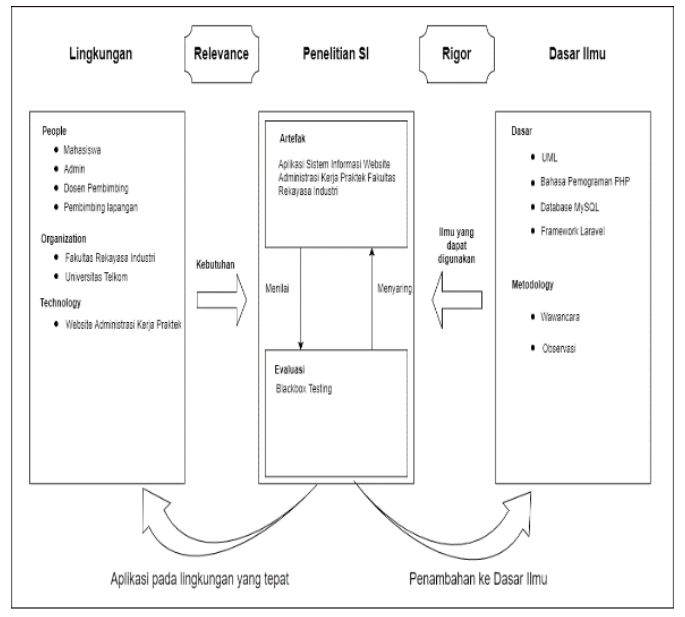

Gambar 1 (Model Konseptual)

Pada gambar di atas menjelaskan model konseptual keseluruhan dalam pembuatan website kerja praktek dan pengabdian masyarakat, tetapi pada penelitian ini peneliti akan menjelaskan pada bagian modul mahasiswa. Permasalahan mahasiswa yang 
terjadi pada administrasi kerja praktek dan pengabdian masyarakat di Fakultas Rekayasa industri yaitu mahasiswa menerima informasi mengenai plotting pembimbing akademik dan pembekalan kerja praktek dan pengabdian masyarakat dengan melalui media sosial yang dinilai kurang efisien, pengumpulan berkas masih menggunakan email dan menjadwalkan waktu presentasi pada masing-masing pembimbing akademik masih manual. Sistem informasi yang dibuat oleh peneliti adalah sistem yang memberikan kemudahan kepada setiap aktor yang terlibat. Sistem informasi website administrasi kerja praktek dan pengabdian masyarakat modul mahasiswa ini juga dapat membantu mahasiswa melakukan proses kerja praktek dan pengabdian masyarakat lebih mudah karena hanya berfokus pada satu sistem website.

Aktor yang terlibat dalam sistem informasi website administrasi kerja praktek dan pengabdian masyarakat yaitu mahasiswa, dosen pembimbing, admin, pembimbing lapangan masing-masing memiliki akses yang berbeda-beda. Selain observasi melakukan wawancara dengan kepala bagian dari Fakultas Rekayasa Industri untuk mendapatkan kebutuhan sistem yang sesuai.

Pada penelitian akan dirancang sebuah aplikasi sistem informasi administrasi kerja praktek dan pengabdian masyarakat berbasis website modul mahasiswa yang nantinya akan melewati tahap pengujian perangkat lunak dengan menggunakan teknik yang terdapat pada pengujian black-box testing.

b. Sistematika Penyelesaian Masalah

Berdasarkan Model Konseptual yang sudah dijelaskan sebelumnya dapat digunakan untuk membantu memecahakn masalah yang sudah diidentifikasi sebelumnya. Sistematika Penelitian merupakan tahapan-tahapan yang dilakukan untuk mendapatkan solusi dari masalah yang sudah diidentifikasi (Simarmata et al., 2021).

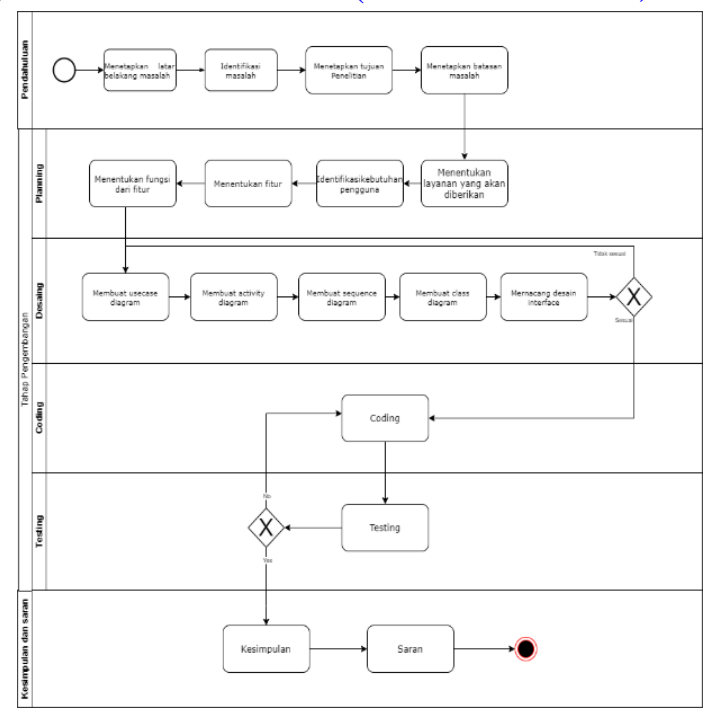

Gambar 2 (sistematika penyelesaian masalah)

1. Tahap Pendahuluan

Pada tahap ini peneliti melakukan identifikasi terhadap masalah pada administrasi kerja praktek dan pengabdian masyarakat di lingkungan Fakultas Rekayasa Industri yang dihadapi mahasiswa dengan melakukan pengamatan atau observasi terhadap 
proses kerja praktek dan pengabdian masyarakat di Fakultas Rekayasa Industri dan pendekatan dengan melakukan wawancara kepada mahasiswa tentang masalah yang dihadapi terkait kerja praktek dan pengabdian masyarakat, dengan hasil ini peneliti dapat memberikan solusi terhadap permasalahan yang timbul.

2. Tahap Pengembangan Sistem

Pada tahap melakukan pengembangan sistem informasi kerja praktek dan pengabdian masyarakat berbasis website ini peneliti menggunakan Metode Extreme Programming, metode ini dianggap lebih tepat diterapkan karena sesuai denngan kebutuhan peneliti, karena metode ini tepat untuk proyek kecil yang tidak perlu memerlukan banyak anggota tim, dan waktu pengembangan yang tidak lama. Dalam pengembangan sistem ini menggunakan Extreme Programming yang terdiri dari 4 tahap yaitu:

\section{- Planning}

Pada tahap planning perencanaan, peneliti melakukan aktifitas perencanaan, seperti mengidentifikasi masalah yang terjadi pada administrasi kerja praktek dan pengabdian masyarakat di Fakultas Rekayasa Industri, menganalisis kebutuhan seperti analisis proses bisnis eksisting terlebih dahulu lalu menentukan target untuk membuat website, dan juga menentukan kebutuhan sistem dan aktor yang akan digunakan nantinya.

- Design

Pada tahap ini peneliti melakukan perancangan pemodelan, perancangan model dimulai dari pemodelan sistem, pemodelan arsitektur hingga pemodelan basis data, pemodelan arsitektur dengan menggunakan diagram UML (Unified Modeling Language) seperti activity diagram, usecase diagram dan sequence diagram dan basis data menggunakan entity relationship diagram dan class diagram.

- Coding

Pada tahap ini peneliti melakukan pemodelan aplikasi yang sebelumnya dilakukan pada tahap perancangan, pada tahap ini peneliti mulai menggunakan framework laravel, database MySQL dan bahasa pemograman PHP dengan metode extreme programming dalam membuat sistem infromasi kerja praktek dan pengabdian masyarakat sesuai dengan kebutuhan.

\section{- Testing}

Tahapan ini dijalankan setelah tahap coding selesai. Peneliti menggunakan metode pengujian black-box untuk melakukan pengujian sistem pada tahap ini untuk mengetahui kesalahan apa saja yang terjadi pada website yang sedang dikembangkan dan menentukan apakah sistem sudah memenuhi kebutuhan yang telah ditentukan dan juga menggunakan metode pengujian usability testing untuk mengetahui apakah aplikasi ini layak untuk digunakan

3. Tahap Kesimpulan dan Saran

Pada tahap ini peneliti melakukan penyusunan kesimpulan terkait semua hasil dari penelitian sesuai dengan tujuan dari penelitian, kesimpulan yang diambil 
berdasarkan data dan analisis yang dibuat pada pengembangan sistem informasi kerja praktek dan pengabdian masyarakat yang nantinya penelitian ini dapat digunakan oleh pembaca untuk mennggambarkan desain aplikasi yang akan dikembangkan nantinya.

\section{Hasil dan Pembahasan}

\section{A. Implementasi Database}

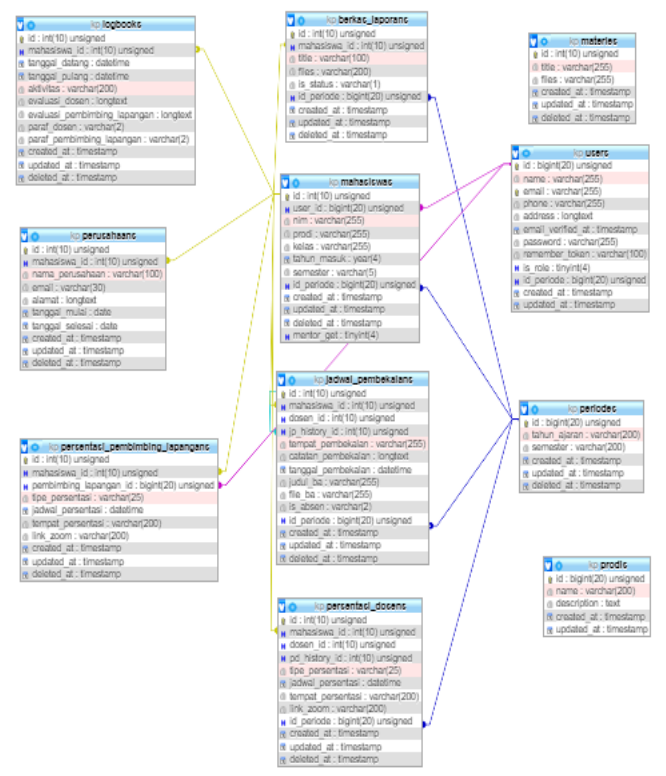

Gambar 3 (Implementasi Database)

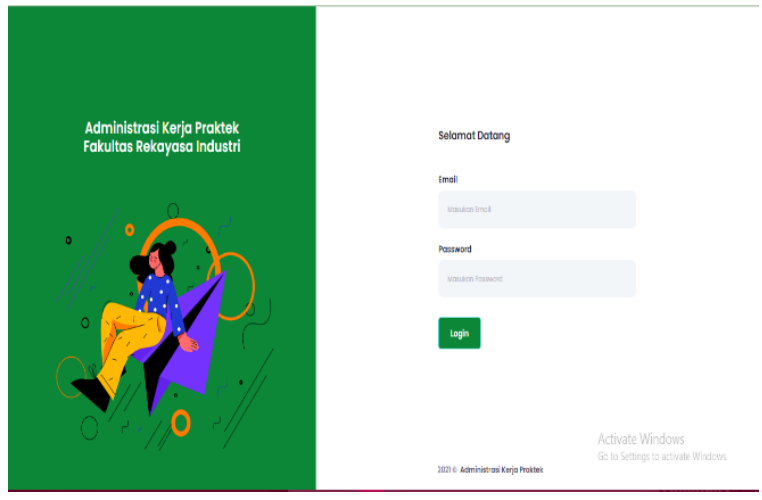

Gambar 4 (Halaman Login) 
Muhammad Fawaz Najib Risal, Nia Ambarsari, Edy sutoyo

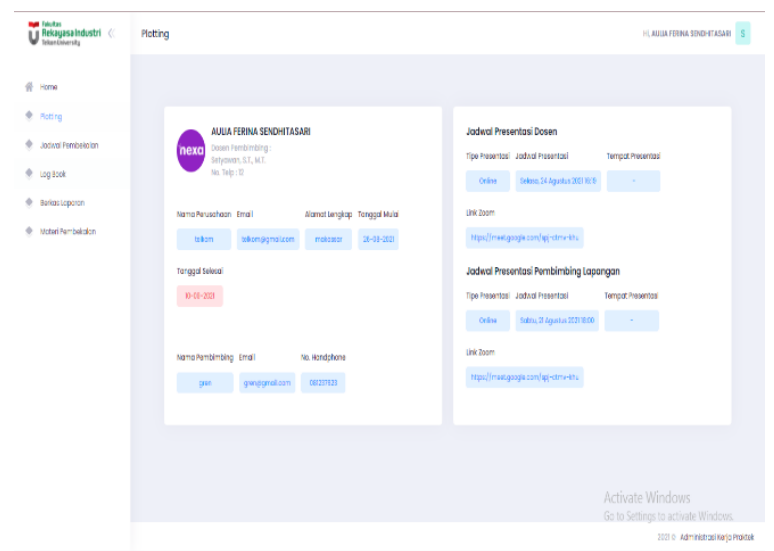

Gambar 5 (Halaman Menu Plotting)

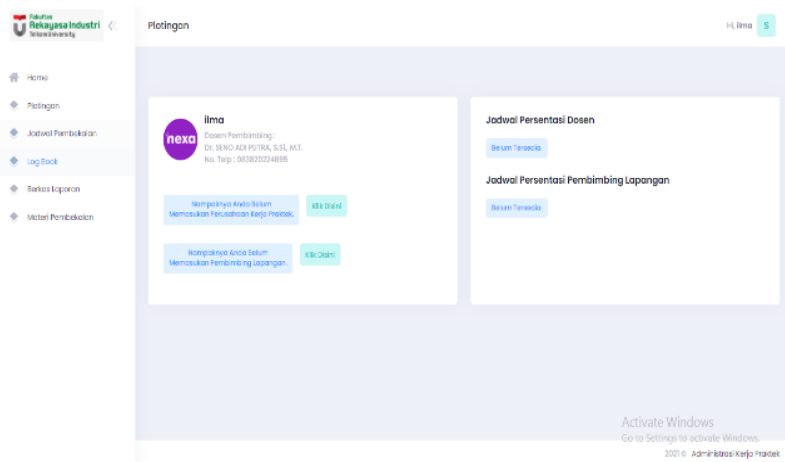

Gambar 6 (Halaman Tampilan awal Menu Plotting)

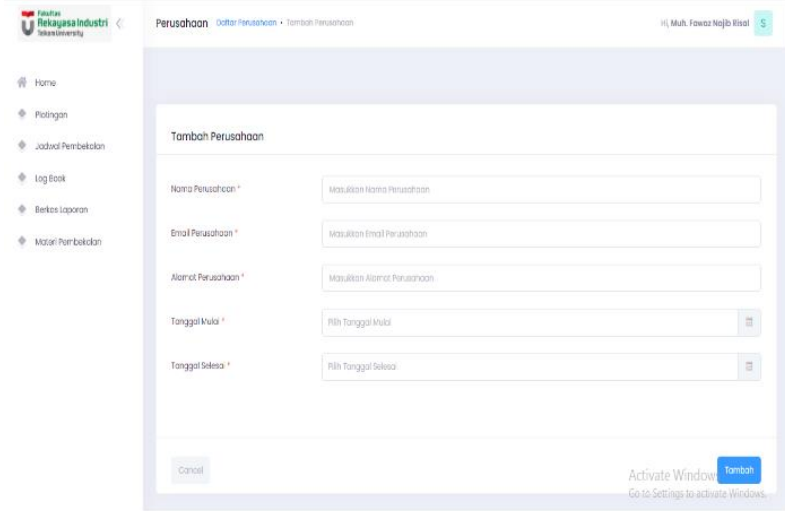

Gambar 7 (Halaman Tambah Data Perusahaan)

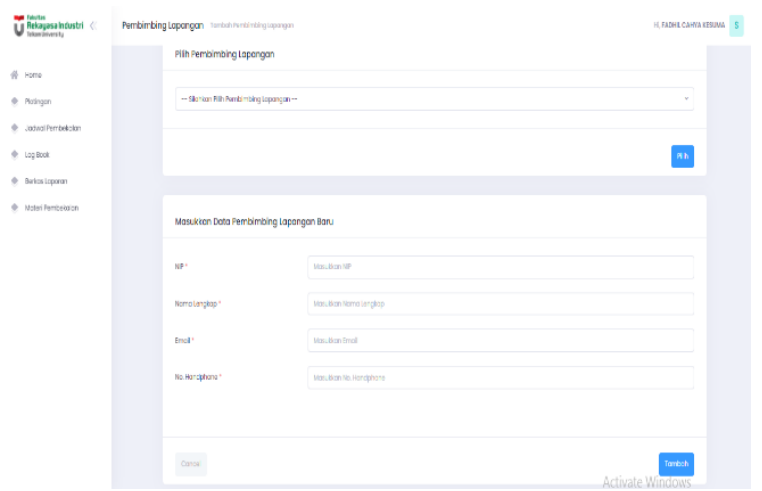

Gambar 8 (Halaman Tambah Data Pembimbing lapangan) 
Pembuatan Sistem Informasi Administrasi Kerja Praktek Dan Pengabdian Masyarakat Berbasis Website

Gambar 9 (Halaman Menu Jadwal Pembekalan)

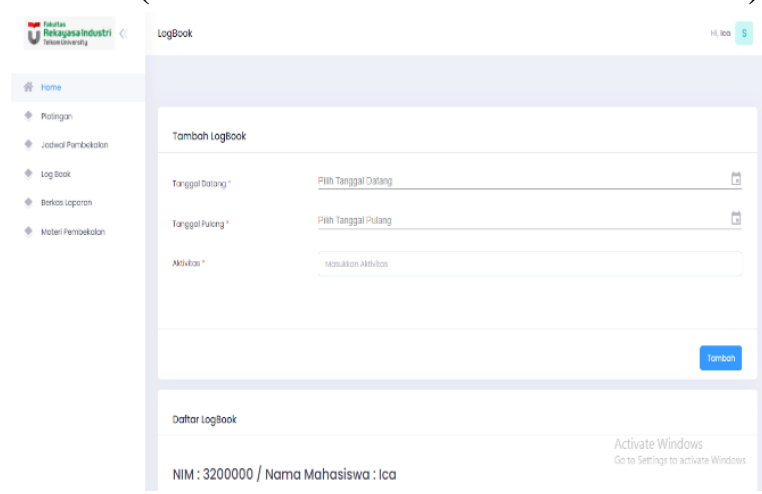

Gambar 10 (Halaman Menu Logbook)

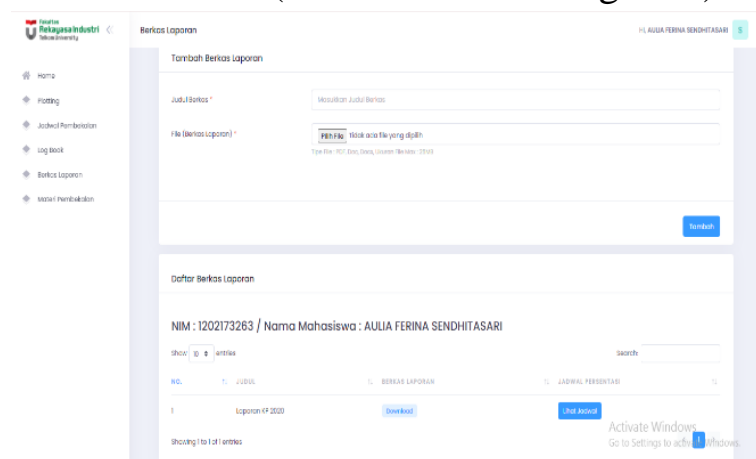

Gambar 11 (Halaman Menu Berkas Laporan)

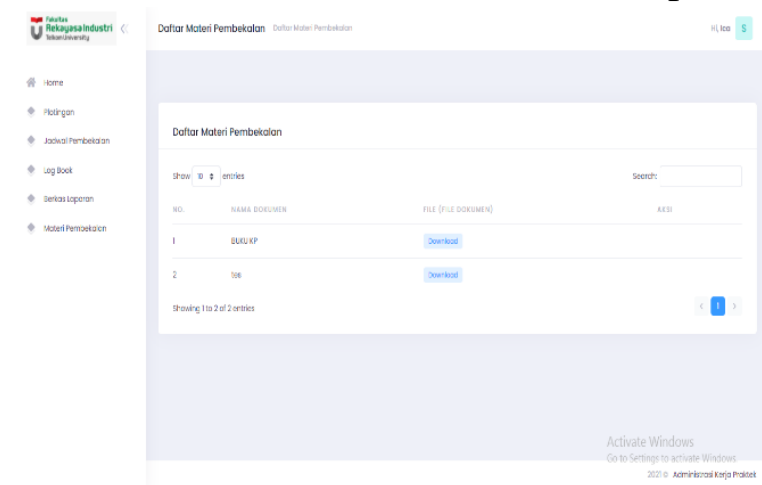

Gambar 12 (Halaman Menu Materi Pembekalan) 


\section{B. Pengujian Perangkat Lunak}

\section{Black-box Testing}

Tabel 1 Hasil Black-box Testing

Dapat disimpulkan hasil dari black-box testing yaitu semua fungsional sistem dalam modul mahasiswa dapat berjalan sesuai yang diharapkan peneliti tetapi ada beberapa yang mengalami bug pada jadwal pembekalan.

\section{Usability Testing}

\begin{tabular}{|c|c|c|c|c|c|c|c|c|c|c|c|c|}
\hline $\begin{array}{l}\text { No. } \\
\text { Responden }\end{array}$ & Q01 & Q02 & Q03 & Q04 & Q05 & Q06 & Q07 & Q08 & Q09 & Q10 & Amount & $\begin{array}{l}\text { Score } \\
\text { (amount } \\
\times 2.5 \text { ) }\end{array}$ \\
\hline R01 & 3 & 4 & 4 & 4 & 4 & 3 & 4 & 4 & 3 & 4 & 37 & 93 \\
\hline R02 & 4 & 3 & 4 & 2 & 4 & 2 & 4 & 2 & 2 & 2 & 29 & 73 \\
\hline R03 & 3 & 2 & 3 & 3 & 2 & 3 & 2 & 3 & 3 & 3 & 27 & 68 \\
\hline R04 & 4 & 3 & 4 & 2 & 4 & 3 & 4 & 2 & 4 & 2 & 32 & 80 \\
\hline R05 & 3 & 3 & 3 & 3 & 3 & 3 & 3 & 3 & 4 & 3 & 31 & 78 \\
\hline R06 & 4 & 3 & 3 & 3 & 4 & 4 & 4 & 3 & 4 & 2 & 34 & 85 \\
\hline R07 & 3 & 3 & 3 & 3 & 3 & 3 & 3 & 2 & 2 & 3 & 28 & 70 \\
\hline R08 & 3 & 3 & 4 & 3 & 4 & 3 & 4 & 3 & 2 & 3 & 32 & 80 \\
\hline R09 & 3 & 4 & 3 & 3 & 4 & 2 & 4 & 3 & 3 & 3 & 32 & 80 \\
\hline R10 & 3 & 3 & 2 & 2 & 2 & 3 & 2 & 2 & 2 & 2 & 23 & 58 \\
\hline R11 & 3 & 3 & 3 & 3 & 3 & 2 & 3 & 3 & 3 & 3 & 29 & 73 \\
\hline R12 & 3 & 3 & 3 & 3 & 3 & 2 & 3 & 3 & 3 & 3 & 29 & 73 \\
\hline R13 & 4 & 4 & 3 & 3 & 4 & 4 & 4 & 3 & 3 & 4 & 36 & 90 \\
\hline R14 & 3 & 3 & 3 & 3 & 4 & 3 & 4 & 3 & 4 & 3 & 33 & 83 \\
\hline R15 & 3 & 3 & 3 & 3 & 3 & 3 & 3 & 3 & 3 & 3 & 30 & 75 \\
\hline R16 & 4 & 4 & 4 & 4 & 3 & 4 & 3 & 4 & 3 & 4 & 37 & 93 \\
\hline R17 & 3 & 3 & 3 & 3 & 4 & 3 & 4 & 3 & 3 & 3 & 32 & 80 \\
\hline R18 & 4 & 3 & 4 & 3 & 4 & 4 & 4 & 3 & 3 & 4 & 36 & 90 \\
\hline R19 & 3 & 2 & 3 & 2 & 3 & 3 & 3 & 2 & 4 & 2 & 27 & 68 \\
\hline \multirow[t]{2}{*}{ R20 } & 3 & 3 & 4 & 3 & 3 & 3 & 3 & 3 & 3 & 4 & 32 & 80 \\
\hline & $\begin{array}{l}\text { Average } \\
\text { Score } \\
\text { (Final } \\
\text { Result) }\end{array}$ & 78 & & & & & & & & & & \\
\hline
\end{tabular}


Table 2 Evaluation of SUS Testing Value

\begin{abstract}
Pengujian usability menggunakan kuisioner pertanyaan terkait variabel usability, hasil pengujian usability testing Berdasarkan jawaban responden dengan menggunakan bantuan google form terhadap 20 responden dapat diperoleh skor ratarata dengan skor 78. Dari segi Acceptability range yang bisa dilihat pada Gambar . Kategori Grade Scale berada pada posisis C dan Adjective Rating berada di posisi Good. Berdasarkan hasil yang diperoleh dari posisi yang didapat, dapat dikatakan bahwa webiste administrasi kerja praktek dan pengabdian masyarakat berada di kategori baik untuk digunakan oleh Mahasiswa.
\end{abstract}

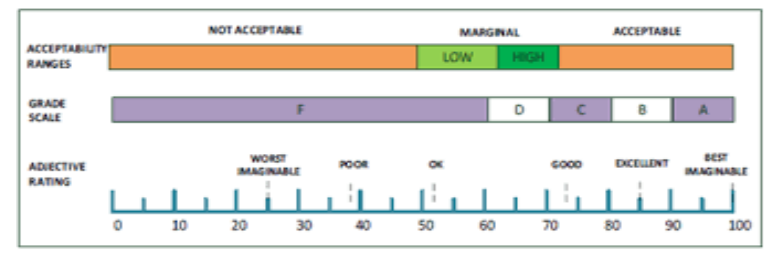

Gambar 13 SUS Score

\title{
Kesimpulan
}

Pada pembuatan sistem informasi Administrasi kerja praktek dan pengabdian masyarakat berbasis website ini hanya membuat pada modul Mahasiswa, adapun fitur dan layanan berikan kepada Mahasiswa yaitu penerimaan informasi terkait Dosen pembimbing dapat dilihat langsung di website kerja praktek dan pengabdian masyarakat, materi pembekalan dan jadwal pembekalan dapat di download dan dilihat langsung oleh Mahasiswa, pengisian logbook melalui website kerja praktek dan pengabdian masyarakat dan pengumpulan berkas laporan kerja praktek dan pengabdian masyarakat dapat diupload langsung oleh mahasiswa serta jadwal presentasi yang di input-kan oleh dosen pembimbing dapat dilihat di website kerja praktek dan pengabdian masyarakat. Dalam pengujian fungsional sistem menggunakan metode blackbox testing hasil yang didapat yaitu sistem dapat berjalan sesuai yang diharapkan, adapun hasil pengujian usability testing Berdasarkan jawaban responden dengan menggunakan bantuan google form terhadap 20 responden dapat diperoleh skor rata-rata dengan skor 78. Dari segi Acceptability range yang bisa dilihat pada Gambar. Kategori Grade Scale berada pada posisis C dan Adjective Rating berada di posisi Good. Berdasarkan hasil yang diperoleh dari posisi yang didapat, dapat dikatakan bahwa webiste administrasi kerja praktek dan pengabdian masyarakat berada di kategori baik untuk digunakan oleh Mahasiswa. 


\section{BIBLIOGRAFI}

Fathoni, M., Fauzi, R., \& Gumilang, S. F. S. (2020). Perancangan Modul Admin Sibengkel Untuk Kebutuhan Administrasi Mitra Dan Admin Sibengkel Dengan Menggunakan Metode Extreme Programming. EProceedings of Engineering, 7(2). Google Scholar

Ghufron, G. (2018). Revolusi Industri 4.0: Tantangan, Peluang, dan solusi bagi dunia pendidikan. Seminar Nasional Dan Diskusi Panel Multidisiplin Hasil Penelitian Dan Pengabdian Kepada Masyarakat 2018, 1(1). Google Scholar

Harto, K. (2018). Tantangan dosen ptki di era industri 4.0. Jurnal Tatsqif, 16(1), 1-15. Google Scholar

HS, H. R. A. (2020). Bunga Rampai Meretas Kampus Masa Depan Gemilang. Desanta Publisher. Google Scholar

Lewis, W. E. (2004). Software testing and continuous quality improvement. Auerbach publications. Google Scholar

Mandag, R. C., Lumenta, A. S. M., \& Rindengan, Y. D. Y. (2017). Pengembangan Sistem Informasi Kuliah Kerja Terpadu (KKT) di Universitas Sam Ratulangi. Jurnal Teknik Informatika, 10(1). Google Scholar

Patzer, A., \& Moodie, M. (2004). Testing Techniques. In Foundations of JSP Design Patterns (pp. 187-197). Springer. Google Scholar

Saputra, D. (2021). Pembangunan Sistem Informasi Manajemen Laboratorium Terpadu Institut Teknologi Kalimantan. Institut Teknologi Kalimantan. Google Scholar

Sidh, R. (2013). Peranan Brainware dalam sistem informasi manajemen. Jurnal Computech \& Bisnis, 7(1), 19-29. Google Scholar

Simarmata, J., Romindo, R., Samala, A. D., Gustiana, Z., Yuswardi, Y., Pakpahan, A. F., Limbong, A., Ardiana, D. P. Y., Latif, N., \& Wanita, F. (2021). Metodologi Riset Bidang Sistem Informasi dan Komputer. Yayasan Kita Menulis. Google Scholar

Sudjiman, P. E., \& Sudjiman, L. S. (2018). Analisis sistem informasi manajemen berbasis komputer dalam proses pengambilan keputusan. TeIKa, 8(2), 55-66. Google Scholar

First publication right:

Jurnal Syntax Fusion: Jurnal Nasional Indonesia

This article is licensed under:

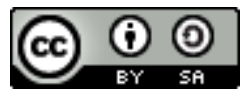

